УДК 663.25.013:338.48-6:330.341.1

\title{
JEL: L66
}

\author{
Hanna Sarkisian \\ $\mathrm{PhD}$, Associate Professor, \\ Odessa National Academy of Food Technologies, \\ Odessa, Ukraine \\ ORCID ID: 0000-0001-7362-3637 \\ e-mail: anutasark@gmail.com \\ Margaryta Liganenko \\ $\mathrm{PhD}$, Associate Professor, \\ Odessa National Academy of Food Technologies, \\ Odessa, Ukraine \\ ORCID ID: 0000-0002-4509-4616 \\ e-mail: margie88svet@gmail.com
}

\section{ANALYSIS OF THE INNOVATIVE ENVIRONMENT OF WINE ENTERPRISES DEVELOPMENT AS AN INFRASTRUCTURE COMPONENT OF WINE ROUTES}

\begin{abstract}
The development of the wine industry as an infrastructural component of wine routes is possible only on a scientific platform, based on innovative transformations, with the support of the state and in close cooperation of all sectors of the economy related to viticulture, winemaking, and tourism. Despite the fact that the problems of management in the field of innovative development at various levels currently given considerable attention, a number of aspects of this issue remain unexplored. Thus, the analytical assessment of the innovation environment of Ukraine from the standpoint of innovation processes effective management in socio-economic systems and identifying the impact nature on the development of wineries is relevant. The main sources of innovative development inhibition are the state and the business environment. The state does not create conditions conducive to the development of the business environment, and also pays insufficient attention to the environment of knowledge production, which is the basis for innovation. This situation is risky for the domestic wine industry. Unfortunately, with the openness and insecurity of the Ukrainian market, European wines will continue to be more affordable. As a result, sales of Ukrainian products may fall, which in turn will exacerbate the fight against European winemakers for the Ukrainian consumer. Fierce competition with world leaders in the wine market dictates the need to improve the quality of Ukrainian wine products while reducing costs. A significant reserve for reducing the cost of wine is to increase the yield of grapes and the introduction of waste-free technologies. Carrying out economic transformations in Ukraine aimed at applying market principles of production regulation and increasing the competitiveness of domestic products, encourages continuous economic development and activity in economic and legal practice, which is an integral element of market economy self-regulation and a tool of responsibility for the inefficient organization of business structures. Ignoring or weakening this work inevitably leads to a crisis, bankruptcy, and liquidation of such enterprises in the wine industry. Given the international experience of highly developed wine regions of the world, it is advisable to develop and support wine tourism as a marketing component for advertising and promotion of local producers of alcoholic beverages as a tourist product, receiving additional economic and social benefits from tourists - wine connoisseurs. The key factors in the development of all wine tourism sites in Ukraine are enterprises and structures related to the production and sale of alcoholic beverages. Their share in the retail food turnover of Ukraine is set within $20 \%$, which is quite high for the country's economy.
\end{abstract}

Key words: innovation environment; wineries; wine; wine routes.

DOI: http://doi.org/10.32750/2020-0205

\section{INTRODUCTION}

The innovativeness of the environment is determined by the level of economic entities innovative activity based on the results of innovation. While the main costs of enterprises in the innovation sphere fall on the purchase of machinery and equipment, less attention is paid to 
research. It is confirmed that to identify trends in the development of enterprises it is necessary to conduct research on the dynamics of the system "subject-environment", based on the theory of innovation environments. Thus, in view of the above, the key tasks of the wine industry are: harmonization of national legislation in the field of viticulture and winemaking to EU requirements, including through grants, foreign donor assistance and international programs; intellectualization of the industry, a systematic staffing program for the wine industry by strengthening the links between viticulture and winemaking in the research and production sphere, as well as in the field of training in higher education institutions and specialized colleges.

Formulation of the problem. The problems of winemaking in Ukraine are currently complex:

- lack of state support forces growers and winemakers to survive alone in the difficult conditions of dynamic change;

- emerging shortage of raw materials winemakers are forced to fill with imported wine materials;

- imbalance and spontaneity of the varietal composition of vineyards will inevitably lead to the loss of traditional (aboriginal) grape varieties, which will affect the quality characteristics of wine;

- increasing the cost of wine products makes it uncompetitive. The consequence of this is a general decline in the economic efficiency of grape production and wine production.

Analysis of recent research and publications. Ukraine's wine market is estimated at 23 million decalitres, or $\$ 800$ USD million. $85 \%$ of wines are produced by Ukrainian companies, $15 \%$ are imported [1]. The dynamics of wine industry development is $5-6 \%$ per year due to increasing the capacity of large enterprises and increasing the volume of bottling. Small producers do not significantly affect the market. Due to the significant costs of obtaining licenses and paying excise taxes, domestic producers are forced to raise prices or reduce the production of cheap wines. In the taste needs of Ukrainian consumers up to 55\% are fortified wines and up to $35 \%$ - semi-dry wines. There is an increase in consumption of cheaper and correspondingly lower quality wines, but in forecast there is an increase in consumption of natural wines [2]. Today in Ukraine more than 50\% of products are fortified wines. Instead, all over the world prefer dry and, to a lesser extent, semi-dry and semi-sweet table wines made by classical technology. As a result, the consumption of fortified wines in post-Soviet countries is declining every year. However, domestic producers continue to produce fortified wines, citing traditional tastes and demand. In fact, it is easier to produce strong and dessert wines than dry wines, and more profitable from the point of view of the enterprise and the state. Due to the inconsistency of the raw material base of viticulture, resource consumption of production capacity, most Ukrainian producers are not able to produce competitive dry wines. The industry is still equipped mainly with morally and physically outdated equipment that allows you to produce only strong and dessert wines. However, some modern Ukrainian producers invest significant funds in the development of vineyards and production facilities, which gives positive results. [2]. Most wine companies do not have a certified product quality management system, which in modern production becomes the most important component of enterprise efficiency. All quality management processes should be integrated into a single system, which clearly defines responsibilities, procedures, processes and resources. In this sense, the problem of introducing innovative technologies and technical means at the wine industry enterprises comes to the fore.

The crisis of the wine industry requires qualitative changes: on the one hand, a balanced policy and effective mechanisms of state support, and on the other hand, the introduction of advanced technologies aimed at innovative development of each enterprise and the industry as 
a whole. The ability to generate new knowledge and implement it effectively plays a crucial role in the success of states. In other words, innovations, knowledge and new information, as the basis of innovative changes, take the production system to a new, high-quality level. In the conditions of revolutionary transformations, Ukraine declares the importance of innovations for the decision of social and economic problems of the state. At the same time, the structural and technological changes that characterize innovative development in Ukraine are spontaneous and unsystematic.

We have a tendency to reduce the market capacity of the wine industry and increase the degree of market openness. This situation is risky for the domestic wine industry. Unfortunately, with the openness and insecurity of the Ukrainian market, European wines will continue to be more affordable, so some buyers who previously could not afford to buy imported wine will abandon the domestic in favor of the European. As a result, sales of Ukrainian products may fall, which in turn will exacerbate the fight against European winemakers for the Ukrainian consumer.

The aim of the study is to analyze the innovation environment in the system of increasing the competitiveness of wineries for the development of wine routes.

Among the current trends in the development of the wine industry in Ukraine is the lower level of consumption of grape wine compared to Europe; aging of vineyards, shortage of table and technical varieties of grapes; reduction of grape wine production against the background of the general increase in alcohol consumption; little state support for the industry; deterrent tariff and non-tariff measures. The reduction of vineyards in Ukraine causes a mismatch between the need for production of raw materials and the capabilities of the raw material base. This leads to a shortage of raw materials, which is filled by imports of wine materials; unsatisfactory varietal composition of grape plantations: lack of varieties for the production of sparkling wines, red and aboriginal varieties; high prices for domestic raw materials and products of its processing; weak financial support of state scientific institutions and educational establishments of the corresponding direction.

A feature of the industry is a relatively long production cycle. Therefore, the issue of attracting long-term investments is quite acute. Viticulture and winemaking need investment for a long time, and the calculation of credit resources here is possible only for 8-9 years after laying the vineyard.

There are about 70 wine producers in domestic winemaking, among which only 28 with production volumes over 300 thousand dal. The main regions of wine production in Ukraine until 2013 were Odessa, Mykolaiv, Kherson regions and the Autonomous Republic of Crimea. In 2013, the share of Odessa, Kherson and Mykolayiv regions in total production was $72.5 \%$. In 2014, the share of these regions reached $97.3 \%$ due to the occupation of the Autonomous Republic of Crimea [3].

With loss of the Crimean enterprises Odessa and Mykolayiv came to the fore. They managed to partially occupy the niche of the Crimean trade marks. In 2015, among the top 5 were the companies "Koblevo", "Tavria", "Niva", "Shabo", "Fruit Master Foods". At the same time, among the enterprises of Odessa region only 7 meet the requirements of competitiveness and only in the regional market. To enter the national and international markets requires a much higher level of enterprises competitiveness [4]. Producers in the Odessa region are negatively affected by high excise rates and license prices, underdeveloped domestic market, low competitiveness of Ukrainian wine [5]. This applies to the entire wine industry of Ukraine as a whole.

Today it is necessary to gradually reduce the import of wine materials with the simultaneous development of the domestic raw material base through the introduction of innovative technologies for grape production, increasing yields and improving product quality. 
Some of the problems can be solved only through a strict but balanced state policy, the other part - through the introduction of research results into production [5].

\section{RESULTS OF THE RESEARCH}

According to the International Organization of Vine and Wine (French: Organisation Internationale de la vigne et du vin; OIV) in 2014, the share of Europe in the total volume of wine produced in the world is $50 \%$ (137.1 million dal.). Ukraine's share in world wine production in 2010-2014 was $0.7 \%$. The enterprises of primary winemaking of the main winegrowing regions of Ukraine are located in Odessa, Mykolayiv, Kherson, Transcarpathia areas. In general, the area of fruit-bearing vineyards in Ukraine in 2014 was about 80 thousand hectares.

The current situation on the Ukrainian wine market is characterized by the following features: according to the data, the production of grape wine in Ukraine is significantly reduced every year, which is due to the crisis in the economy [6]; small producers work mainly locally, in their regions, and do not have a significant impact on the market as a whole; domestic producers are forced to make contributions to the budget for the issuance of licenses. The constant increase in excise taxes has a negative effect on domestic producers, forcing producers to raise the price of their products or reduce production. It should be noted that the current level of grape wine production is lower than planned in the current "Program for the development of viticulture and winemaking in Ukraine until 2025." [7]. Currently, 95\% of wine produced in Ukraine is sold on the domestic market, $5 \%$ - on the foreign market. Most of the imported wines come to Ukraine from Moldova - 83\%, from Georgia - about 11\%, the rest - from France, Macedonia, Hungary, etc. [1].

Among the current trends in the development of the wine industry in Ukraine should also be mentioned the following: lower consumption of grape wine in Ukraine compared to Europe. If in France, Italy, Spain there are 55-60 liters per person, in Ukraine - about 6 liters [8]; preservation of the tendency of vineyards aging, shortage of both table and technical varieties of grapes; reduction of grape wine production against the background of the general increase in alcohol consumption; little or no state support for the industry in crisis conditions, both in terms of administrative measures (e.g., quotas or licensing) and financial (duties, fees); deterrent tariff and non-tariff measures (taxation of excise duty on all types of wine, including collectibles, establishment of a quota on ethyl alcohol).

A feature of the viticulture industry is a relatively long production cycle. It only takes five years for the vineyard to bear fruit, two years for ordinary wine, and much more for vintage wines, sparkling wines and brandy, so the issue of attracting long-term investment in the industry is quite acute. Viticulture and winemaking need investment for a long time, and the calculation of credit resources here is possible only for the eighth or ninth year after laying the vineyard.

Today in Ukraine the total number of companies producing wine products is about 100 . There are about 20 of those who form the domestic market (large and medium producers). With the exit from the market of the Crimean enterprises there was a slight castling of the TOP-5 largest producers. The Odessa and Mykolayiv companies came to the fore. They managed to partially occupy the niche of the Crimean brands. Thus, in the first nine months of 2015, among the top five (without rating) such companies as: "Koblevo" (wine trademark KOBLEVO), agricultural firm "Tavria" (capacity "Tavria", where Inkerman- International now carries out bottling of still wines Inkerman), the company "Niva" (Tairovsky winery"Niva", trademark "Tairove"and trademark "Odessa Steppe"),"Shabo" (trademark Shabo), "Fruit Master Foods" (Ukrainian-Hungarian) - Kotnar enterprise, wines of trademark Bereg Wine, trademark Cotnar, trademark Vinia). 
Table 1

Production of grapes and grape wine in Ukraine

\begin{tabular}{|c|c|c|c|c|c|}
\hline Year & $\begin{array}{c}\text { The area of vineyards } \\
\text { is thousands of } \\
\text { hectares }\end{array}$ & $\begin{array}{c}\text { Crop capacity } \\
\text { tons / hectare }\end{array}$ & $\begin{array}{c}\text { Gross harvest of } \\
\text { grapes } \\
\text { thousand tons }\end{array}$ & $\begin{array}{c}\text { The volume of grape } \\
\text { wine production } \\
\text { million decalitres }\end{array}$ & $\begin{array}{c}\text { Volume of sparkling } \\
\text { production } \\
\text { million } \\
\text { decalitres }\end{array}$ \\
\hline 2010 & 72 & 5,60 & 408,0 & 29,1 & 4,10 \\
\hline 2011 & 70,7 & 5,99 & 336,9 & 17,03 & 3,73 \\
\hline 2012 & 64,2 & 5,32 & 292,9 & 12,51 & 3,39 \\
\hline 2013 & 61,6 & 7,09 & 384,2 & 11,73 & 3,06 \\
\hline 2014 & 44 & 6,4 & 241,0 & 7,2 & 2,6 \\
\hline 2015 & 45,4 & 6,2 & 386,3 & 16,6 & 2,2 \\
\hline 2016 & 45,1 & 5,8 & 377,8 & 14,2 & 1,6 \\
\hline 2017 & 43,5 & 5,6 & 409,6 & 6,671 & 4,978 \\
\hline 2018 & 43,0 & 5,8 & 467,6 & 6,768 & 5,079 \\
\hline
\end{tabular}

The dynamics of the main indicators of viticulture and winemaking development in Ukraine in 2018 shows that the area under vineyards has not changed (43 thousand hectares in 2018, while in 2017 it was 43.5 thousand hectares). In 2018, 527.1 hectares of vineyards were planted in Ukraine: 184.2 hectares in Mykolayiv region, 137.5 hectares in Odessa region, 25.3 hectares in Kherson region, and 18.4 hectares in Zaporizhia region. Despite a slight decrease in the area under vineyards, the gross harvest of grapes in the country has increased slightly due to favorable weather and climatic conditions. In particular, in 2018 Ukraine harvested 467.6 thousand tons of grapes, and in 2017 - 409.6 thousand tons. That is, in 2018 the grape harvest increased by 58 thousand tons, or $14.2 \%$. Also in 2018, the production of grape wine increased slightly: 6768 thousand dal compared to 6671 thousand dal in 2017 (97 thousand dal more, or $+1.5 \%$ ). Brandy production in Ukraine also increased: 2268.9 thousand dal in 2018, which is 113.4 thousand dal more than in 2017 (or $+5.3 \%$ ). These are the official data of the State Statistics Service of Ukraine, which since 2014 are submitted without taking into account the Autonomous Republic of Crimea, Sevastopol and other temporarily occupied territories [9].

An important indicator to pay attention to and which speaks of trends in the market of grape wine products is the production of wine materials. For example, according to the State Statistics Service, the production of cognac wine materials in Ukraine increased: if in 2017 their production amounted to 3985.4 thousand decaliters, then last year this figure reached 4990.2 thousand decaliters $(+25.2 \%)$. The production of wine materials for sparkling wines also increased: in 2018 it amounted to 5079.2 thousand dal, or $2 \%$ (to 4978.2 thousand dal). And also for table wines: 9279.1 thousand dal in 2018 compared to 8654.5 thousand dal in 2017, or $7.2 \%$. At the same time, the production of wine materials for fortified wines decreased significantly. In particular, in 2018 it amounted to 279.9 thousand dal compared to 842.5 thousand dal in 2017 (or 33.2\%). Of course, consumer demand generates supply, and therefore, such indicators indicate that the preferences of Ukrainians are being transformed [9].

Assessment of the competitiveness of regional wineries will be presented in table. 2, where we calculate the regional competitiveness ratio [6]:

$$
\text { competitiveness of the enterprise }=(A / B) /(C / D)<0,75
$$

where:

A- net profit of the enterprise in a particular market;

$\mathrm{B}$ - the share of a specific market for the company's products in the general relevant market; 
$\mathrm{C}$ - net profit of all market participants;

$\mathrm{D}$ - the volume of the entire analyzed market.

If the value is less than 0.75 , it can be stated that the competitiveness of the winery in the market is low, which may be due to either the phase of the product life cycle, or the low level of efficiency of major business processes. Thus, of 13 enterprises of Odessa region only seven meet the requirements of a sufficient competitiveness level and only in the regional wine market. It is obvious that to enter the national and international wine markets requires a much higher level of competitiveness for all surveyed enterprises.

Table 2

Projected production of grapes and wine products for the period up to 2025

\begin{tabular}{|l|c|c|c|}
\hline \multicolumn{1}{|c|}{ Product name } & 2015 & 2020 & 2025 \\
\hline Grapes of table grades, thousand tons & 97,7 & 157,5 & 219,3 \\
\hline Grapes of technical grades, thousand tons & 397,1 & 536,9 & 748,5 \\
\hline Grape wine, thousand dal. & 9800 & 11926 & 14492 \\
\hline Sparkling wines, thousand dal. & 5420 & 6596 & 8017 \\
\hline Ukrainian brandy, thousand dal. & 2462 & 3049 & 3775 \\
\hline
\end{tabular}

Problems of Ukrainian products competitiveness in European markets are exacerbated, as already mentioned, by the low level of state support. In Ukraine, UAH 400 million is spent annually to support vineyards and orchards in the development of viticulture, horticulture and hop growing. Unfortunately, this is a small financial support.

According to available data, up to $86 \%$ of wine materials and up to $88 \%$ of brandy alcohols are imported by domestic producers. In fact, today we are developing winemaking in Moldova (up to $44 \%$ of Moldovan exports) and Georgia (up to 50\% of Georgian exports), Azerbaijan, Armenia, Spain, France and other countries. Obviously, this situation leads to the demise of viticulture as a raw material base of domestic winemaking [3]. The optimal solution to the problem is a gradual decline in imports of wine materials with the simultaneous development of domestic raw materials up to $60 \%$. The underdevelopment of the domestic market has a negative impact on the Ukrainian wine competitiveness.

In the structure of alcohol consumption in Ukraine, the share of wine is $9.0 \%$, while in European countries there is a trend of consistently high levels of wine consumption and a decrease in consumption of vodka and spirits. In average, every Ukrainian drinks 5.8 liters of wine per year, which is one of the lowest in Europe (in Poland -7 liters per person, in the Czech Republic - 16 liters, in Spain and Italy - 40 liters, and in France - a maximum of 60 liters) [10].

Thus, as a result of the study it was determined that the world market of wine and Europe as part of it puts forward its requirements for the production of grapes and the efficiency of its cultivation technologies. In order for Ukraine to occupy its niche in this market, representatives of business and government need to study carefully current world trends and correspond to their direction of development; despite the fact that the main competitors in the Ukrainian market of alcoholic beverages are winemakers from Germany, Hungary, France, Moldova, Bulgaria, Macedonia, the unique combination of soil, climatic and varietal features make it possible to create from Ukrainian grapes exclusive dessert and liqueur wines that have no analogues on the world market; to really promote highly efficient viticulture and winemaking in Ukraine, it is necessary to adopt much-needed legal and regulatory documents, bring them into line with existing standards and harmonize with EU laws and regulations of the international market of grapes and wine; only the most efficient companies have a real chance to survive in the intensification of competition in the domestic wine market.

Innovation is becoming a driving force that can overcome the differences in the functioning of enterprises in the wine industry. Manufacturers have the opportunity to study the 
experience of foreign companies, the introduction of new or significantly improved technologies and processes, new marketing methods and organizational methods in the enterprise in order to achieve a high level of product quality and enter the international market. However, innovation carries the risk of losing its own resources, loss of income, additional costs. During the development and implementation of innovations, the problems are excessive spending of money and time, priorities of competitive development, unsatisfactory market analysis, insufficient information from end users, incomplete interaction between departments of the enterprise.

Thus, the implementation of innovations depends on the financial capabilities of enterprises. Therefore, the market will be dominated by companies that invent the means to research consumer demand, develop and implement new flavors and types of products, and be able to attract investors. Implementation of innovative activities is impossible without a team of highly qualified specialists. Therefore, the priority is to create a management system that can effectively and quickly implement innovations, make optimal use of enterprise resources, achieve a high level of profitability [2].

Among the strategic directions of systemic innovative modernization of the industry are the production provision of modern energy-saving machines, multifunctional equipment, energy modules; effective technologies for growing grape resources with the rational use of their genetic potential and technical resources; complex and deep processing and storage of viticulture products, etc.

In the wine industry, the main thing today should be an experienced engineer-technologist winemaker. He is the legislator for breeders-geneticists, wine-growers-scientists, producers. After all, only 5-6\% of grapes in the world are consumed in the form of raisins, $10 \%$ - in fresh form, and $84-85 \%$ are used for the production of wine, cognac, brandy. However, there is still an advantage of growers over winemakers [12].

Fierce competition with world leaders in the wine market dictates the need to improve the quality of Ukrainian wine products while reducing costs. A significant reserve for reducing the cost of wine is to increase the yield of grapes and the introduction of waste-free technologies. When processing grapes into wine materials, approximately $15-20 \%$ of by-products are formed, the rational use of which makes it possible to obtain additional products needed for certain sectors of the economy. The development and implementation of innovative technologies for the disposal of winemaking by-products can provide significant profits.

The operation and development of powerful wineries is made through the integration of agricultural enterprises with wineries and sales firms. The raw material basis for wine production is the products of agricultural enterprises that supply wine materials directly to wineries and cooperate with a number of intermediary organizations. Wine sales channels on the Ukrainian market include intermediary, wholesale and retail companies that provide the vast majority of trade flows, the share of direct wine sales channels in Ukraine is insignificant. The main commodity segment of the Ukrainian wine market are grape wines, the share of fruit and berry wines is insignificant, which is explained by the existing consumer preferences and traditions of home winemaking. [10].

The main task of marketing in the wine industry is to teach the end consumer the culture of consumption, through which the factors of perception and positioning of new brands in Ukraine are formed. To finance such innovative programs, V. Doronin proposes to create a system of "wine" ("terroir") collection in Ukraine, following the example of France and Italy. In Ukraine, this will allow the formation of "industry terroir marketing", which synthesizes the classic marketing and marketing of territories. Its purpose is to create a mythological value of products produced in the region [10].

In the spring of 2019, with the support of the EU, a pilot project "Wine and Taste Roads" 
was launched in Ukraine, which aims to promote wine and gastronomic routes in various areas. Criteria for the effectiveness of the wine routes development are the originality of the product, its diversity and differentiation; value for money; information and marketing support; availability of qualified staff; infrastructure development; impact on consumption culture; growth of tourist flows in the region; development of wineries, sales growth. The development of wine tourism allows to increase the duration of the tourist season, improve the tourist image of the area, increase the number of tourist arrivals, enrich and differentiate the local tourist product [13].

In 2020 the 26-month project, implemented within the Joint Operational Programme Black Sea Basin 2014-2020 funded by the European Neighbourhood Instrument, will help wine and travel sector businesses and stakeholders in the four participant countries develop common approaches for presenting and promoting their products and services. The project involves project partners and stakeholders from Armenia, Greece, Georgia, and Ukraine. The final positioning and promotion will be achieved through a series of online and offline activities and initiatives. The main initiative is to develop and implement country-level wine routes and incorporate them into a single Black Sea Wine Route. The Black Sea Wine Route will be available at an in-house built ICT platform that will provide travelers and businesses from the entire world with all the necessary information about the route, countries and their offerings, and how they can visit and enjoy one of the oldest and most unique wine regions in the world. The introduction of the common label, The Black Sea Wine Glass Member is another initiative that will unite the countries and bring more recognition to the region as a wine tourism destination [14].

\section{CONCLUSIONS}

Thus, the innovative development of the wine industry of Ukraine has no alternatives and requires the mobilization of all possible resources. The specificity of the industry innovative development is the need to optimize the productive forces in interaction with natural and climatic resources and the size of farms. The key issues of financing innovative development are in the plane of scientific modeling of the market and factor distribution of the created value. Sources of funding for the innovation process are a function of the productive forces and product flows of agriculture.

Innovation is now becoming one of the main factors in shaping the effective development of wine production. In developed countries, $40 \%$ of economic growth is provided precisely through innovation, which has determined a fundamentally new transition from traditional to innovation - innovation science and technology policy.

\section{REFERENCES (TRANSLATED AND TRANSLITERATED)}

1. Azoev G.L, Chelenkov A.P. (2000) Competitive advantages of the firm [in Russian]

2. Andreev V. N., Shebarov A. I. (2011) Technical capital management as a tool to ensure the effectiveness of innovative development of an industrial enterprise. Production organizer, No. 3 (50), 84-88. [in Russian]

3. Aniskin U. P., Lukyanov A.I. (2000) Innovation management [in Russian]

4. Alexandrova V., Skripnichenko M., Fedulova L. (2007) Forecasting the inflow of innovative factors on the economy development. Economics and the formation of a new system and government. No. 2, 9-26. [in Ukrainian]

5. Nesterenko O.S. (2015) Tendencies and prospects for the development of wine industry in Ukraine Retrieved from http://molodyvcheny.in.ua/files/journal/2015/2/104.pdf [in Ukrainian]

6. Agafonov V.E. (2000) Organizational, managerial and innovative aspects of the functioning of small enterprises (thesis. Candidate of Economic Sciences) Nizhny Novgorod State. University, Nizhny Novgorod [in Russian] 
7. Adamanova Z.O. (2005) Innovation strategies of economic development in the minds of globalization: monograph. Krimske navchalno-pedagogic state of the art, Simferopol. [in Ukrainian]

8. Akkoff P. (2002) Akkof about management [in Russian]

9. Viticulture and winemaking today. Movement and industry development Retrieved from https://www.syngenta.ua/news/novini-kompaniyi/vinogradarstvo-ta-vinorobstvo-sogodni-vektor-ruhu-tarozvitku-galuzi [(in Ukrainian]

10. Andriychuk O. Ya. (2008) Innovation culture as an effective mechanism for the functioning of the innovation system of the enterprise. Economics: problems of theory and practice: coll. Science. wash. Dnipropetrovsk. Number 237, Volume S. - P. 559-567 [in Ukrainian]

11. Antonyuk L.L., Poruchnik A.M., Savchuk. V.S. (2003) Innovations: theory, mechanism of development and commercialization. K.: KNEU. [in Ukrainian]

12. How Ukrainian winemakers have grown in 5 years and what else needs to be done Retrieved from https://www.epravda.com.ua/rus/publications/2020/11/16/668037/. [in Russian]

13. The Sea of Wine Project to Promote the Black Sea Region as a Wine Tourism Destination Retrieved from http://inter.onaft.edu.ua/the-sea-of-wine/?lang=en [in English] 


\section{УДК 663.25.013:338.48-6:330.341.1}

\section{JEL: L66}

\section{Ганна Саркісян}

к.т.н., доцент, доцент кафедри туристичного бізнесу та рекреації,

Одеська національна академія харчових технологій,

м. Одеса, Україна

ORCID ID: 0000-0001-7362-3637

e-mail:anutasark@gmail.com

\section{Маргарита Ліганенко}

к.т.н., доцент кафедри туристичного бізнесу та рекреації,

Одеська національна академія харчових технологій,

м. Одеса, Україна

ORCID ID: 0000-0002-4509-4616

e-mail: margie88svet@gmail.com

\section{АНАЛІЗ ІННОВАЦЙНОГО СЕРЕДОВИЩА РОЗВИТКУ ВИНОРОБНИХ ПІДПРИЕМСТВ ЯК ІНФРАСТРУКТУРНОЇ СКЛАДОВОЇ ВИННИХ МАРШРУТІВ}

Анотація. Розвиток виноробної галузі як інфраструктурної складової винних маршрутів можливий лише на науковій платформі, спираючись на інноваційні трансформації, при підтримці держави і в тісній співпраці усіх секторів економіки, які мають відношення до виноградарства, виноробства та туризму. Незважаючи на те, що проблемам управління в сфері інноваційного розвитку на різних рівнях в даний час приділяється значна увага, ряд аспектів даної проблематики залишається невивченим. Так, актуальним $є$ аналітична оцінка інноваційного середовища України з позицій ефективного управління інноваційними процесами в соціально-економічних системах та виявлення характеру впливу на розвиток виноробних підприємств. Головними джерелами гальмування інноваційного розвитку є держава і підприємницьке середовище. Держава не створює умов, сприятливих для розвитку підприємницького середовища, а також недостатньо уваги приділяє середовищу виробництва знань, що є основою для інновацій. Така ситуація $є$ ризиковою для вітчизняної виноробної галузі. Нажаль, при відкритості і незахищеності українського ринку європейські вина і надалі будуть більш доступними. В результаті продажі українського продукту можуть впасти, що в свою чергу загострить боротьбу з європейськими виноробами за українського споживача. Жорстка конкуренція зі світовими лідерами на ринку вина диктує необхідність підвищення якості виноробної продукції України з одночасним зниженням собівартості. Істотним резервом зниження собівартості вина $є$ підвищення врожайності винограду й впровадження безвідходних технологій. Проведення в Україні економічних перетворень спрямованих на застосування ринкових принципів регулювання виробництва і підвищення конкурентоспроможності вітчизняної продукції, спонукає в господарсько-правовій практиці до неперервного інноваційного розвитку та діяльності, що є невід’ємним елементом саморегулювання ринкової економіки та інструментом відповідальності за неефективну організацію роботи підприємницьких структур. Ігнорування чи послаблення зазначеної роботи неодмінно призводить до кризи, банкрутства та ліквідації таких підприємств виноробної галузі. 3 огляду на міжнародний досвід високорозвинених виноробних регіонів світу, доцільним є розвиток і підтримка винного туризму, як маркетингової складової для реклами і просування продукції місцевих виробників алкогольних напоїв як туристичного продукту, отримуючи додаткові економічні та соціальні вигоди від туристів - гурманів вина. Ключовим фактором розвитку ринку винного туризму в Україні виступають підприємства і структури, пов'язані з виробництвом і продажом алкогольної продукції. Їх частка в роздрібному продовольчому товарообігу України становить в межах 20\%, що є досить високим показником для економіки країни.

Ключові слова: інноваційне середовище; виноробні підприємства; вино; винні маршрути. 


\title{
УДК 663.25.013:338.48-6:330.341.1
}

\section{JEL: L66}

\author{
Анна Саркисян \\ к.т.н., доцент, доцент кафедры туристического бизнеса и рекреации, \\ Одесская национальная академия пищевых технологий, \\ г. Одесса, Украина \\ ORCID ID: 0000-0001-7362-3637 \\ e-mail:anutasark@gmail.com
}

\author{
Маргарита Лиганенко \\ г. Одесса, Украина \\ ORCID ID: 0000-0002-4509-4616 \\ e-mail: margie88svet@gmail.com
}

к.т.н., доцент кафедры туристического бизнеса и рекреации,

Одесская национальная академия пищевых технологий,

\section{АНАЛИЗ ИННОВАЦИОННОЙ СРЕДЫ РАЗВИТИЯ ВИНОДЕЛЬЧЕСКИХ ПРЕДПРИЯТИЙ КАК ИНФРАСТРУКТУРНОЙ СОСТАВЛЯЮЩЕЙ ВИННЫХ МАРШРУТОВ}

Аннотация. Развитие винодельческой отрасли как инфраструктурной составляющей винных маршрутов возможно только на научной платформе, опираясь на инновационные трансформации, при поддержке государства и в тесном сотрудничестве всех секторов экономики, которые имеют отношение к виноградарству, виноделию и туризму. Несмотря на то, что проблемам управления в сфере инновационного развития на разных уровнях уделяется значительное внимание, ряд аспектов данной проблематики остается неизученным. Так, актуальным является аналитическая оценка инновационной среды Украины с позиций эффективного управления инновационными процессами в социальноэкономических системах и выявления характера влияния на развитие винодельческих предприятий. Главными источниками торможения инновационного развития является государство и предпринимательская среда. Государство не создает условий, благоприятных для развития предпринимательской среды, а также недостаточно уделяет внимания среде производства знаний, которая является основой для инноваций. Такая ситуация рискованная для отечественной винодельческой отрасли. К сожалению, при открытости и незащищенности украинского рынка европейские вина и в дальнейшем будут более доступными. В результате продажи украинского продукта могут упасть, что в свою очередь обострит борьбу с европейскими виноделами за украинского потребителя. Жесткая конкуренция с мировыми лидерами на рынке вина диктует необходимость повышения качества винодельческой продукции Украины с одновременным снижением себестоимости. Существенным резервом снижения себестоимости вина является повышение урожайности винограда и внедрение безотходных технологий. Проведение в Украине экономических преобразований направленных на применение рыночных принципов регулирования производства и повышение конкурентоспособности отечественной продукции, побуждает в хозяйственно-правовой практике к непрерывному инновационному развитию и деятельности, является неотъемлемым элементом саморегулирования рыночной экономики и инструментом ответственности за неэффективную организацию работы предпринимательских структур. Игнорирование или ослабление указанной работы непременно приводит к кризису, банкротству и ликвидации таких предприятий винодельческой отрасли. Учитывая международный опыт высокоразвитых винодельческих регионах мира, целесообразным является развитие и поддержка винного туризма, как маркетинговой составляющей для рекламы и продвижения продукции местных производителей алкогольных напитков как туристического продукта, получая дополнительные экономические и социальные выгоды от туристов - ценителей вина. Ключевым фактором развития рынка винного туризма в Украине выступают предприятия и структуры, связанные с производством и продажей алкогольной продукции. Их доля в розничном продовольственном товарообороте Украины составляет в пределах 20\%, что является достаточно высоким показателем для экономики страны.

Ключевые слова: инновационная среда; винодельческие предприятия; вино; винные маршруты.

\section{(c) B B-NC-SA}

This work is licensed under Creative Commons Attribution-NonCommercial-ShareAlike 4.0 International License. 